
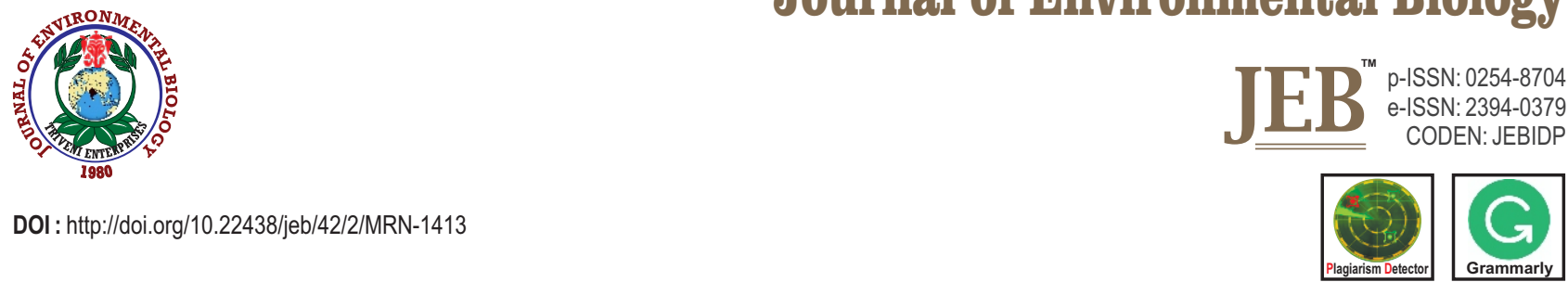

\title{
Environmental factors influencing methanogenic activity in two contrasting tropical lake sediments
}

\author{
S.G.T. Vincent ${ }^{1 *}$, J.H. Salahudeen', P.S. Godson', S.R. Abhijith', A.V. Nath', K.A. Krishnan², N.S. Magesh', S.K. Kumar ${ }^{4}$ and S.A. Moses $^{5}$ \\ ${ }^{1}$ Department of Environmental Sciences, University of Kerala, Kariavattom Campus, Thiruvananthapuram-695 581, India \\ ${ }^{2}$ National Centre for Earth Science Studies, Thiruvananthapuram-695011, India \\ ${ }^{3}$ National Centre for Polar and Ocean Research, Goa-403 804, India \\ ${ }^{4}$ Institute for Ocean Management, Anna University, Chennai-600 025, India \\ ${ }^{5}$ Kerala State Pollution Control Board, Thiruvananthapuram-695 004, India \\ *Corresponding Author Email : salom@keralauniversity.ac.in
} \begin{abstract}
Lake sediments.
Methodology: Sediment and overlying water samples ( $n=5$ each) were collected from Veli and Vellayani lakes of Thiruvananthapuram, Kerala. Samples were analysed for environmental variables using standard protocols. Multivariate analysis was done to study the influence of environmental variables on abundance and activity of MA.
\end{abstract}

Aim: To investigate the influence of environmental variables on the abundance and activity of methanogenic archaea (MA) in Akkulam-Veli and Vellayani

Results: Environmental variables of overlying water and sediment showed significant variation between the two lakes. Salinity and sulphate were more in Akkulam-Veli than Vellayani, as Akkulam-Veli is a brackish lake and temporarily connected with Arabian Sea. Highly reduced sediments of Akkulam-Veli favoured more population of methylotrophic and acetoclastic MA than Vellayani. A distributional difference of MA with depth was observed in both lakes, which is attributed to availability of more labile organic matter. The methylotrophic MA activity was not significantly different between the two lakes; however, their abundance was significantly different. Nevertheless, methane production was higher in Vellayani than in Akkulam-Veli Lake. PCA revealed that Corg and labile organic matter (LOM) were the important environmental variables influencing methane production potential.

Interpretation: Anthropogenic activities like sewage and waste disposal results in increased input of organic matter in lake sediments. The labile organic matter fraction in the sediments favours methanogenic activity thereby resulting in methane production and release from the lakes.

Key words: Labile organic matter, Methanogenic archaea, Methane production, Sulphate reduction, Tropical lakes

How to cite : Vincent, S.G.T., J.H. Salahudeen, P.S. Godson, S.R. Abhijith, A.V. Nath, K.A. Krishnan, N.S. Magesh, S.K. Kumar and S.A. Moses: Environmental factors influencing methanogenic activity in two contrasting tropical lake sediments. J. Environ. Biol., 42, 211-219 (2021). 


\section{Introduction}

Lakes provide recreation, fishing, drinking water, irrigation, transportation, energy and as dumping site for wastewaters. Therefore, settlements, agriculture and industry have been developed extensively to the surroundings of lakes. Among the various states in India, Kerala ranks first in having the largest area of wetlands (Nayar and Nayar, 1997), which includes brackish and freshwater lakes. During recent decades, riverine discharges of nutrients and organic matter have increased significantly due to human interventions within watersheds. The quantity and quality of organic carbon reaching the sediments influence the community structure and function of benthic microorganisms. Wetlands differ in microbial community structure and diversity in sediments, which are controlled by hydrological and nutritional factors (Xu et al., 2017). Moreover, microbial activity is aggravated in tropical wetlands due to high temperature and high rates of organic matter decomposition (Verma et al., 2002) and thus, they may act as sources of green house gases like $\mathrm{CO}_{2}$ and $\mathrm{CH}_{4}$ (Pighini et al., 2018; Zhang et al., 2020).

In tropical lake sediments, sulphate reduction by sulphate reducing bacteria (SRB) and methanogenesis by methanogenic archaea (MA) are important terminal oxidation processes during organic matter mineralization. Sulphate reduction is reported to be the predominant terminal electron accepting process in Ashtamudi estuary in Kerala, India (Vincent et al., 2017). Nevertheless, the mineralization of organic matter is mainly driven by sulphate reduction in the upper $2-4 \mathrm{~cm}$, below that methanogenesis occurs. Sulphate from seawater inhibits methane production in tidal wetlands and salinity has been used as a general predictor of methane emission (Holm et al., 2016). Methane emissions within individual wetland regime are highly variable both spatially and temporally due to heterogeneity of environmental variables (Verma et al., 2002). Several environmental factors of sediments such as temperature, presence of dissolved oxygen, salinity, $\mathrm{pH}$, supply of organic matter, soil texture and mineralogy, electron acceptors and microbial interactions with other anaerobic metabolic group such as sulphate reducing bacteria may influence methanogenesis (Ramesh etal., 1997; Marinho et al., 2012).

Lakes with different trophic status have sediments with different carbon and nutrient concentration with consequently different microbial communities. In tropical conditions, strong precipitation patterns influence significant fluctuations in river discharge and associated hydrological conditions including salinity. In addition to the physical environmental variables, origin and biochemical composition of organic matter also are key factors, which control sediment bacterial composition and activity (Fabiano et al., 2004). The labile fraction of sedimentary organic matter consists of simple organic biopolymer molecules such as proteins, carbohydrates and lipids, which are available for benthic organisms and are rapidly mineralized (Venturini et al., 2012). Due to fast decomposition and turnover rate, labile soil organic pool in wetlands may accelerate the greenhouse effect.
Ultimately, the carbon pool in wetland soils can change from a sink to source, leading to a positive climatic feedback by increasing atmospheric $\mathrm{CO}_{2}$ and $\mathrm{CH}_{4}$ concentrations (Cao et al., 2017). Estuaries are potential source of $\mathrm{CH}_{4}$ into atmosphere (Araujo et al., 2018). Lack of adequate field studies in understanding the source or sinks of $\mathrm{CH}_{4}$ in lakes hampers the global atmospheric budgeting (Araujo et al., 2017). Studies have been undertaken in India in relation to biogeochemistry of $\mathrm{CH}_{4}$ (Ramesh et al., 1997). However, the population and activity of MA as well as their competitors, SRB and their role in controlling methane emission has not been studied so far in tropical estuaries. The aim of the study was to compare the factors influencing the population and activity of MA in Akkulam-Veli (AV), a hyper-eutrophicated brackish water lake and Vellayani, a fresh water lake in Thiruvananthapuram district, Kerala, India.

\section{Materials and Methods}

Study area and sampling: Akkulam-Veli Lake is located in the north western part of Thiruvananthapuram along the Arabian Sea. The lake experiences marine influence during monsoon and is separated from the sea by a sandbar, which is approximately $150 \mathrm{~m}$ long and 20-40 m wide during non-rainy season. Vellayani lake, located in the outskirts of Thiruvananthapuram city is the largest freshwater lake in Kerala. Sediment samples were collected manually, from 5 stations each of Akkulam-Veli and Vellayani lakes, using a core and Van Veen's grab. Samples of overlying water were collected using a Dussart-flask water sampler. Sediment samples for microbiological studies were collected in sterilized sample bottles, brought to laboratory and stored at $4^{\circ} \mathrm{C}$. Cores obtained in each sampling station were segmented in two sections $(0-5 \mathrm{~cm}$ and $5-10 \mathrm{~cm})$ under a nitrogen atmosphere. The remaining sediment samples were maintained under $4^{\circ} \mathrm{C}$ in a refrigerator to perform physico-chemical analyses. Sediment granulometry was determined by differential settling method (Folk, 1974) and classified according to Picard (1971).

Analyses of environmental variables: Physico-chemical and nutrient characteristics of sediment samples like temperature, $\mathrm{pH}$, electrical conductivity (EC), salinity, total kjeldahl nitrogen $(T K N)$, sulphate, organic carbon $\left(\mathrm{C}_{\text {org }}\right)$, organic matter $(\mathrm{OM})$, redox potential (Eh) and sediment granulometry were analyzed by standard methods (Trivedy et al., 1998; APHA, 2017). Organic carbon and organic matter content in sediments were estimated by wet oxidation method (Walkley and Black, 1934).

Biochemical analyses of sediments: Estimation of protein, carbohydrates and lipids from estuarine sediment samples were carried out for assessing the lability of sedimentary organic matter. Protein estimation was done by following the procedures of Hartree (1972); Fabiano et al. (1995) and Lowry et al. (1951). Carbohydrates were analyzed by phenol-sulphuric acid method (Dubois et al., 1956; Kochert, 1978). Lipids from sediment samples were analyzed by acid-dichromate method by Bligh and Dyer (1959) and Parsons et al. (1984). 
Abundance of Methanogenic archaea and sulphate reducing bacteria: Abundance of MA and SRB were enumerated by roll tube method described by Hungate $(1950,1969)$. Mah media was used for MA and postgate media for SRB. Acetate and methanol $(0.1 \mathrm{M})$ substrates were used for the enumeration of acetoclastic and methylotrophic Methanogenic archaea, respectively. The medium and sediment pore water was dispensed into test tubes, sealed with rubber cork and rolled in a wet sponge until the medium solidified inside the tubes. To maintain anaerobic conditions, tubes were flushed with highly pure nitrogen gas before and after rolling the tubes. Methanogenic archaea and sulphate reducing bacteria colony count was taken after one week of incubation and expressed as sediment $\left(\mathrm{CFU} \mathrm{g}^{-1}\right)$.

Methane production potential (MPP) of lake sediments: Microcosm studies were undertaken to analyze the methane production potential of sediments enriched in basal medium, added with different carbon sources ( $0.1 \mathrm{M}$ acetate or $0.1 \mathrm{M}$ methanol). Sediment samples $(1.0 \mathrm{~g})$ from each station were added to $9.0 \mathrm{ml}$ of the respective media in $40 \mathrm{ml}$ serum vials and covered with rubber stopper and aluminium cap assembly. After a week of incubation, gas samples $(0.5-1.0 \mathrm{ml})$ were taken from headspace of the incubation bottles using gas lock syringes and analyzed for the presence of methane in a gas chromatograph (Perkin Elmer, Clarus 580) equipped with Flame lonization Detector. Isothermal separation was performed at $35^{\circ} \mathrm{C}$ in a $30 \mathrm{~m}$ long $0.53 \mathrm{~mm}$, Elite-PLOT Q column, with nitrogen as carrier gas. Samples that contained high methane concentration, in percentage levels, were analyzed on a Thermal Conductivity Detector equipped gas chromatograph (NUCON 5765) packed with PORAPAK Q, 80/100 mesh size $5 \mathrm{~m}$ long column and nitrogen as carrier gas. MPP was expressed in terms of methane (mol $\mathrm{m}^{-3}$ ) produced per day. For estimating sulphate reduction potential (SRP), sediment samples $(1.0 \mathrm{~g})$ were added to $10 \mathrm{ml}$ postgate broth in $40 \mathrm{ml}$ serum vials and incubated for a week. SRP of the sediments was derived from initial and final sulphate concentration in the incubation mixture and expressed in terms of sulphate reduced ( $\mathrm{mol} \mathrm{m}^{-3}$ ) per day (Trivedy et al. 1998).

Statistical analyses: Two-way analysis of variance (two-way ANOVA) was conducted to test for significant differences in the variables between seasons and stations and the interaction effect of stations. Principal Component Analysis (PCA) was used to standardize environmental variables (Reid and Spencer, 2009). Varimax and Kaiser Normalization were carried out for the extraction and interpretation of components. Statistical analyses were conducted using SPSS version: 17.0; SPSS Inc. (2008) and primer 6 softwares.

\section{Results and Discussion}

Akkulam-Veli Vellayani lakes differed from each other significantly with regard to specific environmental variables like water temperature, water and sediment $\mathrm{pH}$, redox potential and clay content. Although Akkulam-Veli and Vellayani lakes were brackish and fresh water lakes respectively, no significant difference were observed in their sediment salinities (Table 1). This was due to the reason that the sampling was done during summer, where Akkulam-Veli lake was detached from the sea by a temporary sand bar and the salinity values indicated freshwater conditions. Nevertheless, the average salinity of Akkulam-Veli lake was 7 fold higher than Vellayani in both water and sediments. The results suggest dominant control of salinity on methanogenesis (Araujo et al., 2018). Although sulphate content of Akkulam-Veli lake was more than Vellayani, the difference was not statistically significant. During sampling period, Akkulam-Veli lake was completely detached from the sea by means of a sand

Table 1: Descriptive statistics of environmental variables and microbial activity in Vellayani and Akkulam-Veli Lake

\begin{tabular}{|c|c|c|c|}
\hline Parameters & Vellayani & Akkulam-Veli lake & ANOVA ( $p$ values) \\
\hline Water temperature $\left({ }^{\circ} \mathrm{C}\right)$ & $32.00 \pm 1.00$ & $29.80 \pm 0.84$ & $0.005^{*}$ \\
\hline Water $\mathrm{pH}$ & $6.74 \pm 0.08$ & $7.30 \pm 0.44$ & $0.02^{*}$ \\
\hline Water electrical conductivity $\left(\mu \mathrm{S} \mathrm{cm}^{-1}\right)$ & $151.40 \pm 22.12$ & $1214 \pm 125$ & 0.096 \\
\hline Water salinity (PSU) & $0.07 \pm 0.01$ & $0.550 \pm 0.1$ & 0.10 \\
\hline Sediment temperature $\left({ }^{\circ} \mathrm{C}\right)$ & $30.60 \pm 0.55$ & $30.00 \pm 0.71$ & 0.17 \\
\hline Sediment $\mathrm{pH}$ & $6.76 \pm 0.12$ & $7.22 \pm 0.35$ & $0.02^{*}$ \\
\hline Sediment electrical conductivity $\left.(\mu \mathrm{S} \mathrm{cm})^{-1}\right)$ & $188.68 \pm 23.92$ & $1215 \pm 1035$ & 0.06 \\
\hline Redox potential $(\mathrm{mV})$ & $-186.60 \pm 23.27$ & $-286.60 \pm 36.49$ & $0.001^{* *}$ \\
\hline Sediment salinity (PSU) & $0.08 \pm 0.01$ & $0.55 \pm 0.50$ & 0.06 \\
\hline Sulphate $\left(\mathrm{mg} \mathrm{g}^{-1}\right)$ & $10.72 \pm 1.74$ & $13.47 \pm 8.00$ & 0.48 \\
\hline Total organic carbon (Corg) (\%) & $3.96 \pm 1.40$ & $2.93 \pm 1.32$ & 0.26 \\
\hline Total organic matter (TOM) (\%) & $6.84 \pm 2.41$ & $5.04 \pm 2.28$ & 0.26 \\
\hline Sand $(\%)$ & $9.45 \pm 9.97$ & $28.75 \pm 18.77$ & 0.08 \\
\hline Silt $(\%)$ & $54.97 \pm 10.14$ & $60.75 \pm 13.22$ & 0.46 \\
\hline Clay $(\%)$ & $31.00 \pm 11.12$ & $10.50 \pm 8.18$ & $0.011^{*}$ \\
\hline Labile organic matter (LOM) $\left(\mu g g^{-1}\right)$ & $25240 \pm 989$ & $22505 \pm 9041$ & 0.52 \\
\hline LOM (\% in TOM) & $41.53 \pm 16.41$ & $46.82 \pm 9.53$ & 0.55 \\
\hline
\end{tabular}

Values are mean of replicates \pm S.D. 
Table 2: Descriptive statistics of microbial activity in Vellayani and Akkulam-Veli Lakes

\begin{tabular}{llll}
\hline Parameters & Vellayani & Akkulam-Veli & ANOVA (p values) \\
\hline Methylotrophic methanogens $(0-5 \mathrm{~cm}) \mathrm{CFU} \mathrm{g}^{-1}$ & $18.00 \pm 14.83$ & $2502 \pm 1220$ & $0.002^{*}$ \\
Methylotrophic methanogens $\left(5-10 \mathrm{~cm}^{*} \mathrm{CFU} \mathrm{g}^{-1}\right.$ & $40.00 \pm 38.73$ & $2652 \pm 1419$ & $0.003^{*}$ \\
Acetoclastic methanogens $(0-5 \mathrm{~cm})(\mathrm{CFU} \mathrm{g})$ & $224.00 \pm 211.85$ & $786 \pm 682$ & 0.12 \\
Acetoclastic methanogens $(5-10 \mathrm{~cm})\left(\mathrm{CFU} \mathrm{g}{ }^{-1}\right)$ & $90.00 \pm 75.17$ & $972 \pm 981$ & 0.08 \\
MPP-methanol $(0-5 \mathrm{~cm})\left(\mathrm{mol} \mathrm{m}^{-3}\right)$ & $94.23 \pm 4.49$ & $72.51 \pm 18.48$ & $0.03^{*}$ \\
MPP-methanol $(5-10 \mathrm{~cm})\left(\mathrm{mol} \mathrm{m}^{-3}\right)$ & $90.74 \pm 3.66$ & $64.11 \pm 19.72$ & $0.02^{*}$ \\
MPP-acetate $(0-5 \mathrm{~cm})\left(\mathrm{mol} \mathrm{m}^{-3}\right)$ & $98.93 \pm 12.40$ & $83.62 \pm 22.48$ & 0.22 \\
MPP-acetate $(5-10 \mathrm{~cm})\left(\mathrm{mol} \mathrm{m}^{-3}\right)$ & $97.04 \pm 6.12$ & $86.59 \pm 17.88$ & 0.25 \\
SRB-acetate $\left.(0-5 \mathrm{~cm})(\mathrm{CFU} \mathrm{g})^{-1}\right)$ & $6.00 \pm 8.94$ & $100 \pm 154.11$ & 0.21 \\
SRB-acetate $(5-10 \mathrm{~cm})(\mathrm{CFU} \mathrm{g}$ & $0.00 \pm 0.00$ & 0.35 \\
SRB-lactate $\left.(0-5 \mathrm{~cm})(\mathrm{CFU} \mathrm{g})^{-1}\right)$ & $70.00 \pm 156.52$ & $74 \pm 15.94$ & 0.90 \\
SRB-lactate $(5-10 \mathrm{~cm})\left(\mathrm{CFU} \mathrm{g} \mathrm{g}^{-1}\right)$ & $86.00 \pm 143.28$ & $28.0000 \pm 3.14$ & 0.72 \\
SRP-lactate $(0-5 \mathrm{~cm})\left(\mathrm{mol} \mathrm{m}^{-3}\right)$ & $22.00 \pm 17.89$ & $0.05 \pm 0.02$ & 0.35 \\
SRP-lactate $(5-10 \mathrm{~cm})\left(\mathrm{mol} \mathrm{m}^{-3}\right)$ & $0.03 \pm 0.038$ & $0.05 \pm 0.05$ & 0.400 \\
\hline
\end{tabular}

MPP - Methane production potential; SRB - Sulphate reducing bacteria; SRP: Sulphate reducing potential

bar. High sulphate concentration results in low methane efflux (Shiau et al., 2016). The population of both methylotrophic and acetoclastic MA were high in Akkulam-Veli than Vellayani lake. This difference of MA abundance was more pronounced in methanol than acetate, where methylotrophic MA was 139 fold more in Akkulam-Veli in the top layer and 66 fold more in bottom layer than Vellayani. A difference in distribution of MA with depth was observed in Akkulam-Veli and Vellayani lakes (Table 2). In Akkulam-Veli, the abundance of acetoclastic and methylotrophic MA was more in bottom layer; however, in Vellayani, acetoclastic MA was abundant in top and methylotrophic MA were more in bottom layer. The distributional difference of MA with depth is attributed to the availability of organic matter and it is reported that the availability and lability index of organic matter decreases with depth (Nedwell et al., 2004; Gonsalves et al., 2011). The reasons for these uncertainties include complex interactions among various physical, geological and biological factors that define each lake system and control organic matter cycling in their sediment (Goni et al., 2003). Shifts in microbial community function and structure can be indicators of environmental stress and ecosystem change in wetland soils (Chambers et al., 2016).

Although MA abundance was favoured by methanol as substrate in Akkulam-Veli, methane production rate was more with acetate than methanol. The difference between the two lakes was observed particularly with abundance of methylotrophic MA and methane production rate with acetate as substrate. This means that methylotrophic methanogenic activity was not significantly different between the two lakes, although their population was different. In contrast, the abundance of acetoclastic MA was not different between the two lakes; however, the difference in methanogenic activities was statistically significant. Hence, it is understood that number of bacteria necessarily does not reflect microbial activity. Generally, methane production rates are higher in sediments of hypereutrophic lakes than oligotrophic lakes (Huttunen et al.,
2003). However, methane production was more in Vellayani lake than in hyper-eutrophicated Akkulam-Veli lake (Fig. 1). This can be explained by electron donor limitations or presence of inhibitors, which can potentially inhibit methanogenesis (Roden and Wetzel, 2003). Moreover, different types of anthropogenic disturbance experienced in Akkulam-Veli lake might have increased microbial diversity, but decreased their metabolic activity (Jin et al., 2017). Akkulam-Veli is a coastal lake and during sampling period it was completely detached from marine influence. Nevertheless, the presence of non-competitve substrates like methanol, methylamine (Winfrey and Ward, 1983) might have favoured the abundance of methylotrophic MA in Akkulam-Veli lake. Hence, it can be conceived that hypereutrophic lakes with higher Corg availability in sediments has highest catabolic diversity, when the microbial communities are able to efficiently use a broader range of substrates (Torres et al., 2011). The presence of MAand SRB in same depth reveals that the distribution of abundant MA and SRB are mutually exclusive. Viable population of SRB corresponds to Corg and sulphate concentration in the sediment (Vincent and Raj, 2018). It is predicted that in low salinity bottom sediments such as fresh water lakes, sulphate reduction is inhibited and methane formation gets elevated. However, it was surprising to note that in Vellayani, despite lower salinity values, sulphate reduction rate was much higher in the bottom sediments than Akkulam-Veli, which had periodic marine influence. In freshwater environments, where available sulphate is usually limited, sulphate reduction still occurs but methanogenesis usually dominates (Nedwell et al., 2004).

The influence of environmental variables on MPP was analysed by multivariate analysis. Principal component analysis (PCA) generated four principal components for both Akkulam-Veli and Vellayani lakes. In Akkulam-Veli lake, the first principal component accounted for $32.84 \%$ of the total variance, whereas, PC2, PC3 and PC4 explained 268.08, 25.03 and $14.05 \%$ of the total variance, respectively. The first component includes Corg, LOM, CHO, PRT and LIP (Tables 3, 4). In Vellayani lake, the first 
Table 3: Principal ComponentAnalysis for Akkulam-Veli lake

\begin{tabular}{llll}
\hline Factor loadings & PC 1 & PC 2 & PC 3 \\
\hline Temperature & -.022 & -.012 & .115 \\
pH & .015 & -.090 & -.010 \\
EC & -.003 & -.003 & .109 \\
TDS & -.002 & -.006 & .110 \\
Salinity & -.003 & -.003 & .109 \\
Sulphate & .007 & -.095 & .008 \\
Sediment temperature & .064 & -.039 & .023 \\
Sediment pH & -.019 & .104 & -.007 \\
Sediment EC & -.063 & .009 & .078 \\
Sediment redox potential & -.020 & .104 & -.007 \\
Sediment salinity & -.038 & .072 & .029 \\
Total organic carbon & .067 & -.014 & .011 \\
Sand & .042 & .088 & -.027 \\
Silt & -.025 & -.100 & .056 \\
Clay & -.055 & -.041 & -.027 \\
TOM & .067 & -.014 & .011 \\
Carbohydrate & .058 & -.013 & .050 \\
Lipid & .040 & -.019 & .078 \\
Protein & .075 & .011 & -.045 \\
LOM percentage & -.065 & .009 & -.035 \\
LOM percentage of TOM & -.027 & .009 & .014 \\
MA Methanol1 & .046 & .055 & .025 \\
MA Methanol2 & .036 & .089 & .000 \\
MAAcetate1 & .027 & .048 & .065 \\
MAAcetate2 & .007 & .034 & .089 \\
MPP Methanol1 & -.075 & -.009 & .008 \\
MPP Methanol2 & .041 & .092 & -.020 \\
MPP Acetate1 & .039 & -.076 & -.047 \\
MPP Acetate2 & -.066 & -.049 & .083 \\
SRB Acetate1 & -.040 & .077 & -.004 \\
SRB Acetate2 & -.048 & .050 & -.036 \\
SRB Lactate1 & .074 & .028 & -.071 \\
SRB Lactate2 & .045 & .027 & -.099 \\
SRP1 & -.077 & -.011 & .020 \\
SRP2 & .041 & -.049 & .074 \\
Eigen value & 13.234 & 9.304 & 8.868 \\
\% of variance & 37.812 & 26.582 & 25.336 \\
Cumulative \% & 37.812 & 64.395 & 89.730 \\
\hline
\end{tabular}

principal component accounted for $38.18 \%$ of the total variance. However, PC2, PC3 and PC4 accounted for 23.81, 23.63 and $14.39 \%$ of the total variance respectively. In Vellayani lake, the first component included salinity, Corg, clay content, sediment $\mathrm{EC}$, water TDS and water $\mathrm{pH}$. The third component was redox potential and $\mathrm{EC}$ of overlying water. The fourth component include water salinity and negative loading of sediment sulphate. Among the two lakes, the environmental variables of water in AkkulamVeli did not influence MPP. However, in case of Vellayani, water TDS and $\mathrm{pH}$ had an influence on MPP. Labile carbon is regarded as the most active fraction of organic carbon in soils with rapid turn over rates compared to refractory organic carbon (Zou et al., 2005). LOM\% was more in Akkulam-Veli than Vellayani. Higher rates of decomposition of sedimentary organic carbon in the surface sediments contribute to the availability of easily
Table 4: Principal ComponentAnalysis for Vellayani lake

\begin{tabular}{llll}
\hline Factor loadings & PC 1 & PC 2 & PC 3 \\
\hline Temperature & .308 & -.009 & -.844 \\
pH & .516 & .811 & -.200 \\
EC & -.331 & .178 & .880 \\
TDS & -.010 & -1.000 & -.002 \\
Salinity & -.260 & .416 & .776 \\
Sulphate & .906 & -.131 & -.199 \\
Sediment temperature & .303 & .399 & -.765 \\
Sediment pH & -.459 & -.845 & .276 \\
Sediment EC & .909 & .216 & -.271 \\
Sediment redox potential & .552 & .433 & .712 \\
Sediment salinity & .925 & .091 & -.183 \\
Total organic carbon & .916 & .288 & .107 \\
Sand & -.880 & -.420 & -.156 \\
Silt & .109 & .623 & .535 \\
Clay & .991 & .025 & -.038 \\
TOM & .915 & .288 & .109 \\
Carbohydrate & .047 & -.826 & .562 \\
Lipid & .415 & .847 & .274 \\
Protein & -.655 & -.511 & .548 \\
LOM percentage & .020 & -.216 & .971 \\
LOM percentage of TOM & -.895 & -.345 & -.110 \\
MA Methanol1 & .027 & .835 & -.537 \\
MA Methanol2 & -.783 & .479 & -.107 \\
MAAcetate1 & .633 & .519 & -.566 \\
MAAcetate2 & .368 & .871 & .306 \\
MPP Methanol1 & .824 & .458 & .026 \\
MPP Methanol2 & .018 & .231 & -.877 \\
MPP Acetate1 & .462 & -.849 & -.087 \\
MPP Acetate2 & -.887 & .391 & -.108 \\
SRB Acetate1 & .412 & .216 & .876 \\
SRB Acetate2 & .052 & .999 & .013 \\
SRB Lactate1 & .441 & -.331 & .834 \\
SRB Lactate2 & .436 & .529 & .561 \\
SRP1 & -.823 & -.099 & .139 \\
SRP2 & .652 & -.272 & -.606 \\
Eigen value & 12.987 & 10.162 & 9.092 \\
\% of variance & 37.105 & 29.035 & 25.978 \\
Cumulative \% & 37.105 & 66.140 & 92.118 \\
\hline
\end{tabular}

degradable fraction. This is reflected in the abundance of MA and $\mathrm{SRB}$, which was more in Akkulam-Veli than Vellayani. The composition and activities of microbial communities are regulated by the quality and availability of carbon (Torres et al., 2011). The LOM pool was contributed more by carbohydrates in both lakes followed by protein. Carbohydrate fraction was 14 and 20 fold more than protein in Akkulam-Veli and Vellayani, respectively. The dominance of carbohydrates may be because of more refractory composition compared to lipids and proteins, which are rapidly utilized (Danovaro et al., 2000). Generally, higher contribution of labile organic carbon to total organic carbon indicates potential threat from the increasingly speedy global warming (Cao et al., 2017). Release of labile substrates is one important factor controlling microbial production of methane (Wang et al., 2017). However, in both Akkulam-Veli and Vellayani 

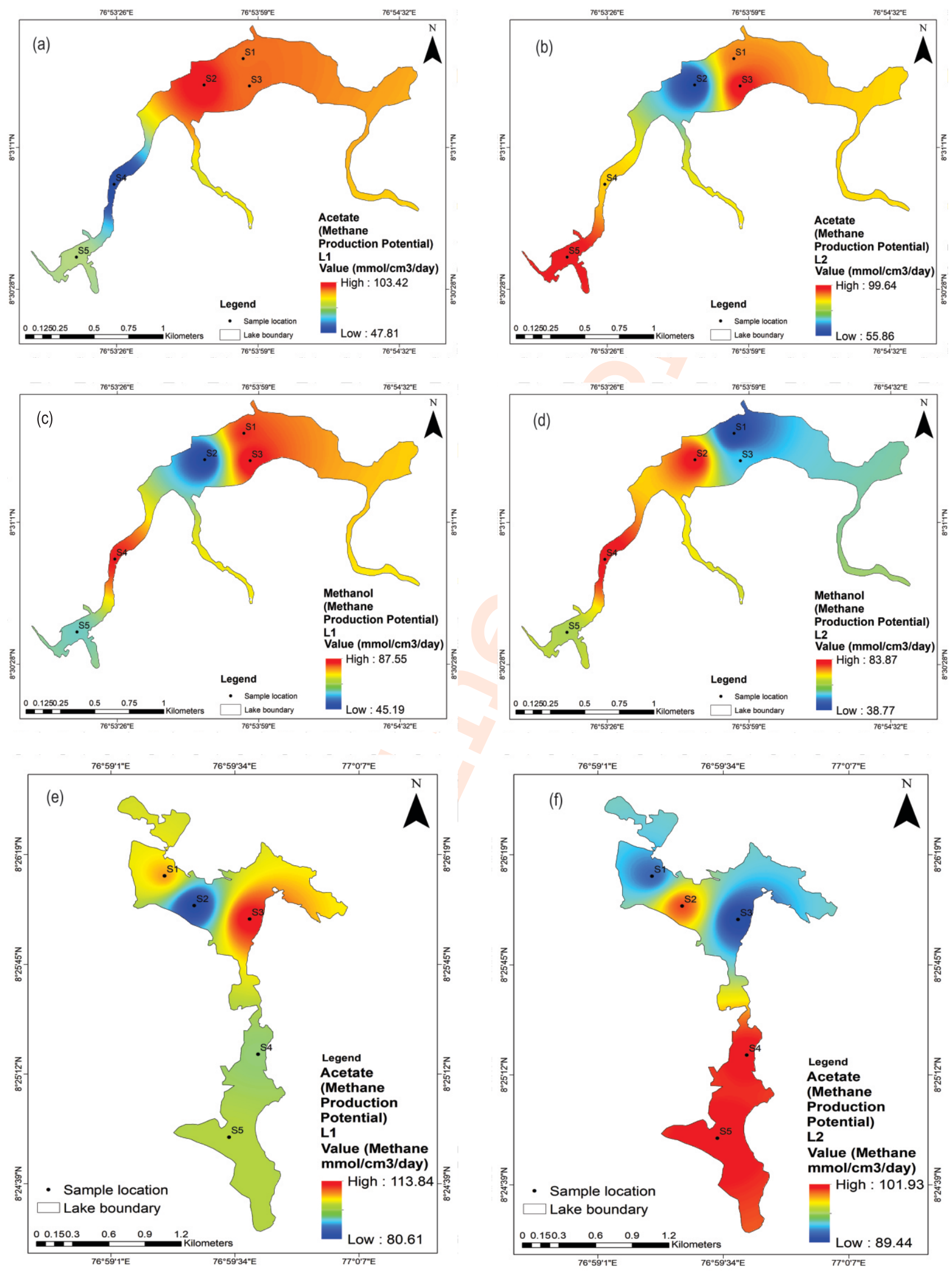

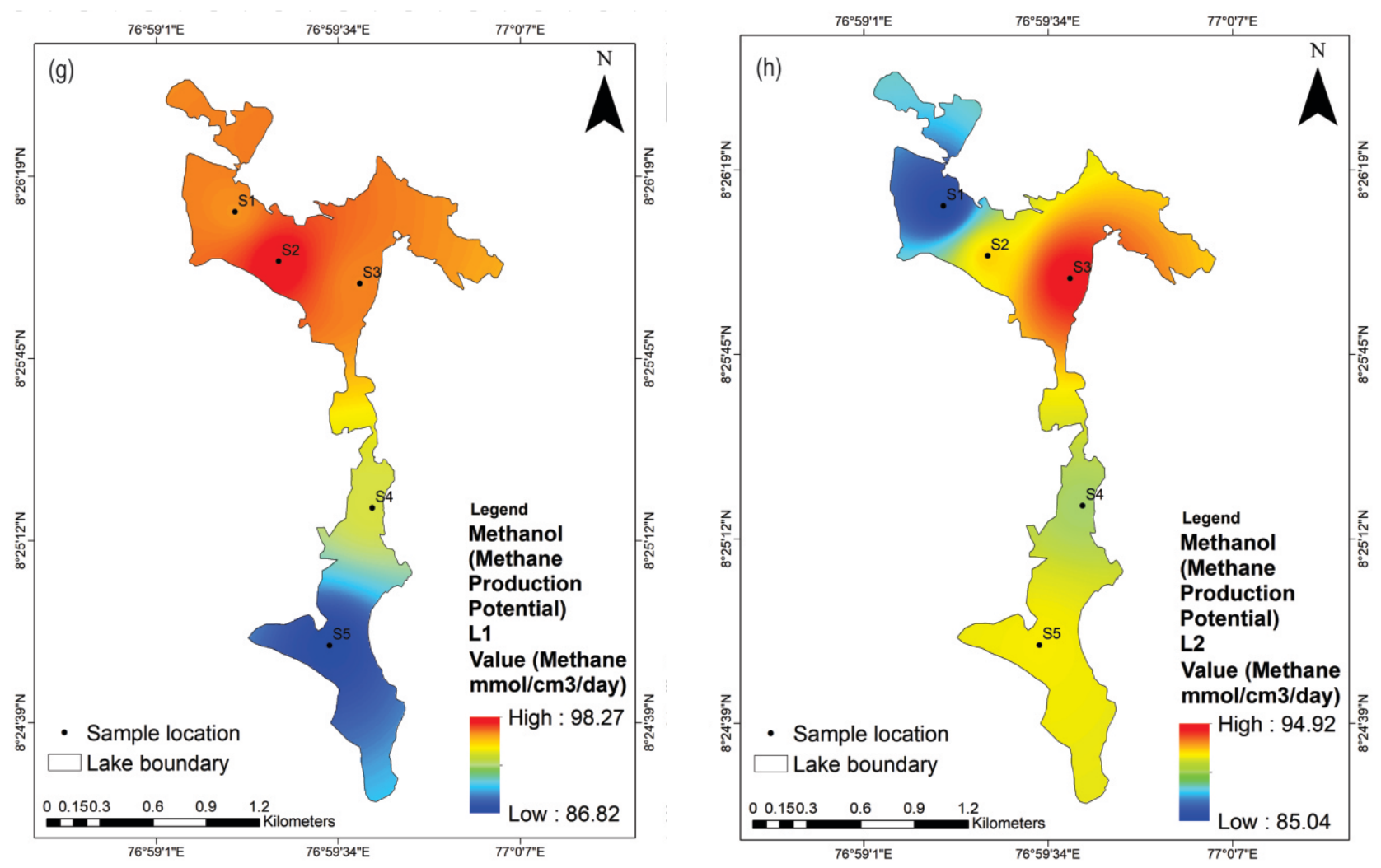

Fig. 1: Methane production potential in AV and Vellayani lake sediments; (a) Acetate (Methane Production Potential L1 value in AV lake sediments (b) Acetate (Mathane Production Potential L2 value in AV lake sediments; (c) Methanol (Methane Production Potential L1 value in AV lake sediments (d) Methanol (Mathane Production Potential L2 value in AV lake sediments; (e) Acetate (Methane Production Potential L1 value in Vellayani lake sediments (f) Acetate (Mathane Production Potential L2 value in Vellayani lake sediments and (g) Methanol (Methane Production Potential L1 value in Vellayani lake sediments (h) Methanol (Mathane Production Potential L2 value in Vellayani lake sediments.

lakes the contribution of labile organic carbon to total carbon pool was less than $50 \%$. Moreover, the anaerobic conditions and high productivity of wetland ecosystems may enhance carbon accumulation in wetland soils (Cao et al., 2015). In Arabian Sea and mangrove sediment of Goa, India, protein fraction of sediments was found to be important factor affecting natural methane production. All three components of LOM, CHO, PRT and LIP were the first PC in Akkulam-Veli lake; however, LOM was not a PC in Vellayani lake. The difference can be attributed to the difference in sedimentary granulometry of the lakes (Gonsalves et al., 2011). Clay content was three fold more in Vellayani than Akkulam-Veli and the difference was statistically different $(p<0.05)$. Clay was found to be the first PC in Vellayani. However, in Akkulam-Veli, sediment granulometry was not a PC. However, the percentage sand was three fold more in Akkulam-Veli than Vellayani. Labile organic carbon was higher in sandy sediment, which suggest that high methane production in sandy sediment can be due to increased lability of organic matter.

Lake depth can also affect the quality of organic matter reaching the sediments. In deep lakes, sediment organic matter undergoes intense decomposition in the water column due to prolonged period of settling. Consequently, low amount of labile organic carbon reach the sediments in deep lakes (Suess, 1980). Akkulam-Veli is a shallow and Vellayani a deep lake which explains more of labile organic matter in Akkulam-Veli in addition to its hyper eutrophication status. Anthropogenic activities in the hinterland as well as coastal area alter the physicochemical setting of estuaries (Jennerjahn and Mitchell, 2013). Moreover, riverine input into Akkulam-Veli might have transported decomposed organic matter composing of undegraded sewage sludge and freshwater algae and bacteria (Soetaert and Herman, 1995). Downstream transportation of organic matter undergoes decomposition and is not supplemented with fresh labile organic matter because autochthonous production is limited to marine part of Akkulam-Veli (Middelburg etal., 1996).

Moreover, in the Akkulam-Veli lake, a large amount of city's municipal wastewater enters the wetland untreated through a system of drains due to deficiencies in the sewage collection system (Ghermandi et al., 2016). Leading to high sedimentation rate, which reduce the contact time between organic matter and dissolved oxygen in the water column, and therefore, can contribute to higher concentration of carbon and nutrients in 
sediment. Although human activities leading to release of untreated sewage promotes methane emission in wetlands (Martinez-Cruz and Gonzalez-Valencia, 2017), restoration of coastal wetlands can convert them into sink of carbon, thus reducing their methane production potential (Yang et al., 2020). Among the various environmental factors, Corg and labile organic matter was found to influence the methanogenic activity in both lakes. The dominance of methanogenic activity over sulphate reduction in Akkulam-Veli lake is attributed to the utilization of non-competitive substrates by MA. Increased methane production potential in Akkulam-Veli than Vellayani is attributed to untreated sewage and waste disposal.

\section{Acknowledgments}

The authors thank the University of Kerala and National Centre for Earth Science Studies for providing the laboratory facilities. We also thank the funding received from the Ministry of Environment, Forests and Climate Change.

\section{Add-on Information}

Authors' contribution: S.G.T. Vincent: Funding acquisition, Conceptualization, Supervision, Writing, Reviewing, editing; J.H. Salahudeen: Methodology, data curing, reviewing, editing; P.S. Godson: Data curing, reviewing, editing; S.R. Abhijith, A.V. Nath: Methodology, writing; K.A. Krishnan, N.S. Magesh, S.K. Kumar, S.A. Moses: Data curing, reviewing.

Research content: The research content is original and has not been published elsewhere

\section{Ethical approval: NotApplicable}

Conflict of interest: The authors declare that there is no conflict of interest.

\section{Data from other sources: NotApplicable}

Consent to publish: All authors agree to publish the paper in Journal of Environmental Biology.

\section{References}

Abhijna, U. G., R. Ratheesh and A.B. Kumar: Distribution and diversity of aquatic insects of Vellayani lake in Kerala. J. Environ. Biol., 34, 605 (2013).

APHA: Standard Methods for Examination of Water and Wastewater. $23^{\text {nd }}$ Edn., APHA, AWWA, WPCF, Washington DC, USA (2017).

Araujo, J., A. Pratihary, R. Naik, H. Naik and S.W.A. Naqvi: Benthic fluxes of methane along the salinity gradient of a tropical monsoonal estuary: Implications for $\mathrm{CH}_{4}$ supersaturation and emission. Marine Chemi., 202, 73-85 (2018).

Araujo, J., S.W.A. Naqvi, H. Naik and R. Naik: Biogeochemistry of methane in a tropical monsoonal estuarine system along the west coast of India. Estuarin.Coastal ShelfScie., 207, 435-443 (2017).

Bligh, E.G. and W.J. Dyer: A rapid method of total lipid extraction and purification. Canadian J. Bioche. Physiol., 37, 911-917 (1959).
Cao, L., J. Song, Q. Wang, X. Li, H. Yuan, N. Li and L. Duan: Characterization of labile organic carbon in different coastal wetland soils of Laizhou Bay, Bohai Sea. Wetlands, 37, 163-175(2017).

Cao, Q., R. Wang, H. Zhang, X. Ge and J. Liu: Distribution of organic carbon in the sediments of Xinxue River and the Xinxue River constructed wetland, China. PloS ONE, 10 (2015).

Chambers, L.G., R. Guevara, J.N. Boyer, T.G. Troxler and S.E. Davis: Effects of salinity and inundation on microbial community structure and function in a mangrove peat soil. Wetlands, 36, 361-371 (2016).

Danovaro, R., D. Marrale, A. Dell'Anno, N.D. Croce, A. Tselepides and M. Fabiano: Bacterial response to seasonal changes in labile organic matter composition on the continental shelf and bathyal sediments of the Cretan Sea. Progress in Oceanography, 46, 345-366 (2000).

Dubois, M., A. Kyle, J. K. Gilles, P.A. Hamilton, T. Rebers and F. Smith: Colorimetric method for determination of sugars and related substances. Analy. Chemi., 28, 350-356 (1956).

Fabiano, M., R. Danovaro and S. Fraschetti: A three-year time series of elemental and biochemical composition of organic matter in subtidal sandy sediments of the Ligurian Sea (Northwestern Mediterranean). Contin. ShelfRes., 15, 1453-1470 (1995).

Fabiano, M., V. Marin, C. Misic, M. Moreno, V. Salvo and L. Vezzulli: Sedimentary organic matter and bacterial community in microtidal mixed beaches of the Ligurian Sea (NW Mediterranean). Chemi. Ecol., 20, 423-435 (2004).

Folk, R.L.: Petrology of Sedimentary Rock. Hemphill Publishing Company, Austin, Texas, 182 p. (1974).

Ghermandi, A., A.M. Sheela and J. Joseph: Integrating similarity analysis and ecosystem service value transfer: Results from a tropical coastal wetland in India. Ecosy. Servi., 22, 73-82 (2016).

Goñi, M.A., M.J. Teixeira and D.W. Perkey: Sources and distribution of organic matter in a river-dominated estuary (Winyah Bay, SC, USA). Estua. Coas. Shelf Sci., 57, 1023-1048 (2003).

Gonsalves, M., C.E.G. Fernandes, S.O. Fernandes, D.L. Kirchman and P.A.L. Bharathi: Effects of composition of labile organic matter on biogenic production of methane in the coastal sediments of the Arabian Sea. Environ. Monit. Assess., 182, 385-395 (2011).

Hatree, E.F.: Determination of protein: A modification of the Lowry method that gives a linear photometric response. Anal. Biochem., 48, 422-427 (1972)

Holm, G.O., B.C. Perez, D.E. McWhorter, K.W. Krauss, D.J. Johnson, R.C. Raynie and C.J. Killebrew: Ecosystem level methane fluxes from tidal freshwater and brackish marshes of the Mississippi River Delta: Implications for coastal wetland carbon projects. Wetlands, 36, 401-413(2016).

Hungate, R.E.: A roll tube method for cultivation of strict anaerobes. In: Methods in Microbiology.Academic Press, Vol. 3, pp. 117-132 (1969).

Hungate, R.E.: The anaerobic mesophilic cellulolytic bacteria. Bacteriol. Rev., 14, 1-49 (1950).

Huttunen, J.T., J. Alm, A. Liikanen, S. Juutinen, T. Larmola, T. Hammar, J. Silvola and P.J. Martikainen: Fluxes of methane, carbon dioxide and nitrous oxide in boreal lakes and potential anthropogenic effects on the aquatic greenhouse gas emissions. Chemosphere, 52,609-621 (2003).

Jennerjahn, T.C. and S.B. Mitchell: Pressures, stresses, shocks and trends in estuarine ecosystems-An introduction and synthesis. Estua. Coas. Shelf Sci., 130, 1-8 (2013).

Jin, X., Y. Ma, Z. Kong, W. Kou and L. Wu: The variation of sediment bacterial community in response to anthropogenic disturbances of Poyang Lake, China. Wetlands, 39, 63-73 (2017).

Kochert, G.: Protein determination by dye binding. In: Handbook of Phycological Methods: Physiological and Biochemical Methods, Cambridge University Press London, pp. 91-93 (1978).

Lowry, O.H., N.J. Rosebrough, A.L. Farr and R.J. Randall: Protein 
measurement with the Folin phenol reagent. J. Biol. Chem., 193, 265-275 (1951).

Marinho, C.C., E. A. Campos, J.R.D. Guimarães and F. A. Esteves: Effect of sediment composition on methane composition and production in the transition zone of a mangrove (Septiba Bay, Rio de Janaeiro, Brazil). Brazilian J. Biol., 72, 429-436 (2012).

Martinez-Cruz, K., R. Gonzalez-Valencia, A. Sepulveda-Jauregui, F. Plascencia-Hernandez, Y. Belmonte-Izquierdo and F. Thalasso: Methane emission from aquatic ecosystems of Mexico City. Aqua. Sci., 79, 159-169 (2017).

Middelburg, J.J., G. Klaver, J. Nieuwenhuize, A. Wielemaker, W. de Haas, T. Vlug and J.F.W.A van der Nat: Organic matter mineralization in intertidal sediments along an estuarine gradient. Marine Ecol. Prog. Ser., 132, 157-168 (1996).

Nayar, S. and N.M. Nayar: Wetlands In: The Natural Resources of Kerala (Eds.: K.B. Thampi, N.M. Nayar, C.S. Nayar). WWF State Office, Trivandrum, Kerala (1997).

Nedwell, D.B., T.M. Embley and K.J. Purdy: Sulphate reduction, methanogenesis and phylogenetics of the sulphate reducing bacterial communities along an estuarine gradient. Aqua. Micro. Ecol., 37, 209-217 (2004).

Parsons, T.R., Y. Maita and C.M. Lalli: A manual of chemical and biological methods for seawater analysis. Pergamon, Oxford sized algae and natural seston size fractions. Marine Ecol. Prog. Ser., 199, 43-53 (1984).

Picard, M.D.: Classification of fine-grained sedimentary rocks. J. Sedime. Res., 41, 179-195(1971).

Pighini, S., M. Ventura, F. Miglietta and G. Wohlfahrt: Dissolved greenhouse gas concentrations in 40 lakes in the Alpine area. Aqua. Sci., 80, 32 (2018).

Ramesh, R., G.R. Purvaja, D.C. Parashar, P.K. Gupta and A.P. Mitra: Anthropogenic forcing on methane efflux from polluted wetlands (Adyar River) of Madras City, India. Ambio, 26, 369-374 (1997).

Reid, M.K. and K.L. Spencer: Use of principal components analysis (PCA) on estuarine sediment datasets: The effect of data pretreatment. Environ. Pollu., 157, 2275-2281 (2009).

Roden, E.E. and R.G. Wetzel: Competition between Fe (III)-reducing and methanogenic bacteria for acetate in iron-rich freshwater sediments. Micro. Ecol., 45, 252-258 (2003).

Shiau, Y., M.R. Burchell, K.W. Krauss, F. Birgand and S.W. Broome: Greenhouse gas emissions from a created brackish marsh in eastern North Carolina. Wetlands, 36,1009-1024 (2016).

Soetaert, K. and P.M.J Herman: Carbon flows in the Westerschelde estuary (The Netherlands) evaluated by means of an ecosystem model (MOSES). Hydrobiologia, 311, 247-266 (1995).

SPSS, Statistical Package for the Social Sciences, version 17.0, Chicago: SPSS Inc (2008).

Suess, E.: Particulate organic carbon flux in the oceans-Surface productivity and oxygen utilization. Nature, 288, 260-263 (1980).

Torres, I.C., K.S. Inglett and K. R. Reddy: Heterotrophic microbial activity in lake sediments: Effects of organic electron donors. Biogeochemistry, 104, 165-181 (2011).

Trivedy, R.K., P.K. Goel and C.L. Trisal: Practical Methods in Ecology and Environmental Science. Enviromedia Publications, Karad, pp. 40110 (1998).

Venturini, N., A.L. Pita, E. Brugnoli, F. Garcia-Rodríguez, L. Burone, N. Kandratavicius, M. Hutton and P. Muniz: Benthic trophic status of sediments in a metropolitan area (Rio de la Plata estuary): Linkages with natural and human pressures. Estua. Coas. Shelf Sci., 112, 139-152 (2012).

Verma, A., V. Subramanian and R. Ramesh: Methane emissions from a coastal lagoon: Vembanad Lake, West Coast, India. Chemosphere, 47, 883-889 (2002).

Vincent, S.G.T. and R. Raj: Occurrence and activity of sulphate reducing bacteria in selected estuarine sediments of South Kerala, India. Int. J. Ecol. Environ. Sci., 44, 191-198 (2018).

Vincent, S.G.T., R.R. Reshmi, S.J. Hassan, K.D. Nair and A. Varma: Predominant terminal electron accepting processes during organic matter degradation: Spatio-temporal changes in Ashtamudi estuary, Kerala, India. Estua. Coas. Shelf Sci., 198, 508-517 (2017).

Walkley, A. and I.A. Black: An examination of the Degtjareff method for determining soil organic matter, and a proposed modification of the chromic acid titration method. Soil Sci., 37, 29-38 (1934).

Wang, J., C. Song, A. Hou and F. Xi: Methane emission potential from freshwater marsh soils of Northeast China: Response to simulated freezing-thawing cycles. Wetlands, 37, 437-445 (2017).

Winfrey, M.R. and D.M. Ward: Substrates for sulfate reduction and methane production in intertidal sediments. Appli. Environ. Microbio., 45, 193-199(1983).

Xu, S., Y. Wang, C. Guo, Z. Zhang, Y. Shang, Q. Chen and Z. Wang: Comparison of microbial community composition and diversity in native coastal wetlands and wetlands that have undergone longterm agricultural reclamation. Wetlands, 37, 99-108 (2017).

Yang, H., J. Tang, C. Zhang, Y. Dai, C. Zhou, P. Xu, D.C. Perry and X. Chen: Enhanced carbon uptake and reduced methane emissions in a newly restored wetland. J. Geophy. Res. Biogeosci., 125, e2019JG00522 (2020)

Zhang, S., F. Zhang, Z. Shi, A. Qin, H. Wang, Z. Sun, Z. Yang, Y. Zhu, S. Pang and P. Wang: Sources of seasonal wetland methane emissions in permafrost regions of the Qinghai-Tibet Plateu. Scient. Rep., 10, 7520 (2020).

Zou, X.M., H.H. Ruan, Y. Fu, X.D. Yang and L.Q. Sha: Estimating soil labile organic carbon and potential turnover rates using a sequential fumigation-Incubation procedure. Soil Biol. Bioche., 37, 1923-1928 (2005). 